\title{
The role and yield-forming effect of silicon application based on the example of global research
}

\author{
Rola i plonotwórcze efekty stosowania krzemu na przykładzie światowych badań
}

\author{
Urszula Sienkiewicz-Cholewa*, Aleksandra Zajączkowska
}

\begin{abstract}
Summary
Silicon (Si) is not assigned to the group of components necessary for plants, yet studies proved that it affects plant growth and yield positively. Silicon is abundant in soils, but for plants it is available as unstable orthosilicate acid $\mathrm{H}_{4} \mathrm{SiO}_{4}$. Plants with the highest demand for silicon include monocotyledonous species (rice, sugarcane, wheat) which uptake it through an active transport and accumulate it at the level $>1 \%$ Si in dry matter. Silicon has been applied to soil and plants in the production of crops worldwide for many years. Low and very low levels of available silicon has been found in tropical soils and the plants grown under this climate positively responded to fertilization with $\mathrm{Si}$ (increase in crop yields has been observed). Beneficial activity of $\mathrm{Si}$ is especially pronounced at biotic (diseases and insects) and abiotic (drought and salinity) stress. The results of the most recent studies proved that inclusion of Si into fertilization programme is also reasonable in the countries with a temperate climate. The article presents forms of application and yield-forming effects of silicon in the selected crop species.
\end{abstract}

Key words: silicon, Si sources for plants, soil and foliar application, plant yielding

\section{Streszczenie}

Krzem (Si) nie należy do składników niezbędnych dla roślin, ale coraz więcej danych literaturowych podaje, że może wpływać korzystnie na wzrost i plonowanie roślin. Pierwiastek ten występuje w glebach w bardzo dużej ilości, ale dla roślin jest dostępny tylko w postaci niestabilnego kwasu ortokrzemowego $\mathrm{H}_{4} \mathrm{SiO}_{4}$. Największe zapotrzebowanie na krzem wykazują gatunki jednoliścienne (ryż, trzcina cukrowa, pszenica), które pobierają go za pomocą transportu aktywnego i akumulują w ilości > 1\% Si w s.m. Na świecie krzem od wielu lat stosowany jest w produkcji roślinnej doglebowo i dolistnie. Niski i bardzo niski poziom krzemu dostępnego dla roślin wykazują gleby klimatu tropikalnego i subtropikalnego. Rośliny uprawiane w tym klimacie reagują na aplikację krzemu wzrostem plonów. Korzystne działanie Si jest szczególnie wyraźne w warunkach stresu biotycznego (choroby, szkodniki) i abiotycznego (stres suszy, stres solny). Wyniki najnowszych badań dowodzą, że włączenie krzemu do nawożenia ma uzasadnienie również w krajach o klimacie umiarkowanym. W pracy przedstawiono metody aplikacji i efekty plonotwórcze stosowania krzemu u wybranych roślin.

Słowa kluczowe: krzem, źródła Si dla roślin, aplikacja doglebowa i dolistna, plonowanie roślin

Instytut Uprawy Nawożenia i Gleboznawstwa - Państwowy Instytut Badawczy

Zakład Herbologii i Technik Uprawy Roli

Orzechowa 61, 50-540 Wrocław

*corresponding author: u.sienkiewicz@iung.wroclaw.pl

ORCID: 0000-0003-3788-9440 


\section{Wstęp / Introduction}

Krzem (Si) w glebie występuje w postaci różnego rodzaju minerałów, glinokrzemianów, krzemianów sodu, wapnia, potasu oraz krzemionki $\mathrm{SiO}_{2}$, bardzo trudno rozpuszczalnych i odpornych na wietrzenie. Krzem, krzemionkę, kwarc (krystaliczna postać krzemionki) i piasek (zanieczyszczone ziarna kwarcu) można uznać za synonimy. Każdy kilogram gleby zawiera zależnie od pochodzenia od 50 do $400 \mathrm{~g}$ (5-40\%) dwutlenku krzemu. Jedyną dostępną formą krzemu dla roślin w roztworze glebowym jest kwas ortokrzemowy $\mathrm{H}_{4} \mathrm{SiO}_{4}$, nazywany także monokrzemowym, którego zawartość jest niewielka i często niewystarczająca dla roślin. Rośliny uprawiane na glebach piaszczystych, teoretycznie zasobnych w krzem mogą odczuwać jego niedobory (Brogowski 2000).

Największe ilości krzemu rośliny gromadzą w liściach, bezpośrednio pod warstwą epidermy w postaci bezpostaciowych polimerów $\mathrm{SiO}_{2} \times \mathrm{nH}_{2} \mathrm{O}$ (żel krzemionkowy), tworzących tzw. nierozpuszczalną warstwę kutykularno-krzemową. Proces polimeryzacji kwasu w roślinie przebiega bardzo szybko w ciągu 7-12 h. Im więcej krzemu pobierze roślina tym grubsza tworzy się warstwa krzemowa (Knight i Kinrade 2001; Sommer i wsp. 2006). W mniejszej ilości krzem gromadzą korzenie. Warstwa krzemowa zalegająca pod kutykulą wzmacnia tkanki roślin i stanowi swoistą, ochronną barierę mechaniczną, która spełnia następujące funkcje:

- ochrona tkanek przed wnikaniem patogenów i żerowaniem szkodników,

- wzmocnienie ścian komórkowych epidermy i zwiększenie odporności roślin na wyleganie,

- zwiększenie efektywności fotosyntetycznej roślin w wyniku lepszej ekspozycji liści na promienie słoneczne,

- ograniczenie transpiracji naskórkowej i ochrona roślin przed utratą wody (Gao i wsp. 2004, 2006; Ma 2004; Laane 2011; Sahebi i wsp. 2015).

Badania Lumsdona i Farmera (1995) dowodzą, że istnieje silna konkurencja między jonami fosforanowymi $\mathrm{H}_{2} \mathrm{PO}_{4}^{-}$i krzemowymi $\mathrm{H}_{3} \mathrm{SiO}_{4}^{-}$o miejsca sorpcji w glebie. Zaadsorbowany fosfor jest wypierany przez krzem do roztworu glebowego i staje się dostępny dla roślin. Jony kwasu monokrzemowego w środowisku kwaśnym reagują także z ruchomym glinem tworząc słabo rozpuszczalne glinokrzemiany, zmniejszając toksyczność tego pierwiastka dla roślin. Związki krzemowe optymalizują żyzność gleby poprzez poprawę jej właściwości wodnych, fizycznych i chemicznych oraz utrzymanie składników odżywczych w postaci dostępnej dla roślin (dotyczy to fosforu).

\section{Krzem w roślinach / Silicon in plants}

Najwięcej krzemu, tj. powyżej 1\% w s.m., gromadzą rośliny zwane ,akumulatorami” krzemu reprezentowane
Tabela 1. Światowa produkcja i zawartość krzemu w pędach roślin Table 1. Global production and Si content in plants shoots

\begin{tabular}{l|c|c}
\hline \multicolumn{1}{c|}{$\begin{array}{c}\text { Gatunek } \\
\text { Species }\end{array}$} & $\begin{array}{c}\text { Produkcja [mln ton] } \\
\text { Production [mln tons] }\end{array}$ & $\begin{array}{c}\text { Zawartość w pędach [\%] } \\
\text { Content in shoots [\%] }\end{array}$ \\
\hline $\begin{array}{l}\text { Trzcina cukrowa } \\
\text { Sugar cane }\end{array}$ & 1840 & 1,5 \\
\hline $\begin{array}{l}\text { Ryż } \\
\text { Rice }\end{array}$ & 739 & 4,2 \\
\hline $\begin{array}{l}\text { Pszenica } \\
\text { Wheat }\end{array}$ & 672 & 2,5 \\
\hline $\begin{array}{l}\text { Burak cukrowy } \\
\text { Sugar beet }\end{array}$ & 270 & 2,3 \\
\hline $\begin{array}{l}\text { Soja } \\
\text { Soybeen }\end{array}$ & 241 & 1,5 \\
\hline $\begin{array}{l}\text { Kukurydza* } \\
\text { Maize }\end{array}$ & 873 & 0,83 \\
\hline
\end{tabular}

*kukurydza nie jest klasyfikowana jako roślina akumulująca krzem, ale pobiera z plonami duże ilości $\mathrm{Si}$ - maize is not classified as silicon accumulating plant, bad takes with yields large amounts $\mathrm{Si}$

przez gatunki wiodące w światowej produkcji, takie jak ryż, trzcina cukrowa, pszenica, buraki i soja (Matichenkov i Calvert 2002; Tubana i wsp. 2016) (tab. 1).

Największe ilości krzemu wynoszone są z gleby przez trzcinę cukrową (300-700 kg Si/ha), ryż (150-300 kg Si/ha) i pszenicę (50-150 kg Si/ha). Łącznie uprawy te mogą przyczyniać się do „usuwania” z plonem od 210 do $224 \mathrm{mln}$ ton Si rocznie na całym świecie (Hodson i wsp. 2005; Tubana i wsp. 2016). Z badań wynika, że krzem pobierany jest przez ryż i trawy za pomocą transportu aktywnego przy udziale specyficznych transporterów (Ma 2004; Farooq i Dietz 2015). Rośliny bobowate natomiast nie mają zdolności gromadzenia krzemu i usuwają ten składnik ze swoich tkanek (tzw. rejective uptake).

Krzem odgrywa ważną rolę w mineralnym odżywianiu roślin, zwłaszcza w przypadku gatunków o dużej akumulacji tego pierwiastka. Gleby subtropikalne i tropikalne mają ogólnie niski i bardzo niski poziom dostępnego krzemu i rośliny reagują na nawożenie tym składnikiem wzrostem plonów. Od lat w krajach tropikalnych stosuje się nawożenie doglebowe i dolistne krzemem. W literaturze wskazuje się, że włączenie krzemu do nawożenia w celu zwiększenia plonów i utrzymania wydajności upraw ma uzasadnienie w krajach o klimacie umiarkowanym. Niektórzy autorzy uważają, że krzem może być uznany za pierwiastek niezbędny dla roślin (Epstein i Bloom 2005; Liang i wsp. 2005).

\section{Krzem w glebie / Silicon in soil}

Na rozpuszczalność i mobilność krzemu w glebie wpływa głównie odczyn, który reguluje procesy adsorpcji-desorpcji kwasu krzemowego z faz stałych gleby. Maksymalna adsorpcja, głównie przez minerały ilaste, występuje 
w odczynie obojętnym i zasadowym o $\mathrm{pH}$ 7-9. W środowisku bardzo kwaśnym o $\mathrm{pH}<4,7$ krzem dostępny dla roślin wiązany jest przez jony glinu i manganu występujące w nadmiarze w glebie i wytrąca się w postaci trudno rozpuszczalnych krzemianów. W ten sposób krzem skutecznie łagodzi toksyczne działanie glinu i manganu na korzenie roślin. Uwalniany do roztworu glebowego kwas krzemowy jest niestabilny i już przy stężeniu $>2 \mathrm{mM}$ wykazuje wysoką skłonność do polimeryzacji i tworzy większe, nierozpuszczalne cząstki krzemionki (kwas polikrzemowy), tzw. żel koloidalny. Zatem polimeryzacja kwasu zmniejsza jego rozpuszczalność, a tym samym biodostępność. Kwasy polikrzemowe łączą cząsteczki gleby tworząc mostki krzemionkowe, które poprawiają jej strukturę i zdolność zatrzymywania wody. Dotyczy to głównie gleb lekkich (Knight i Kinrade 2001; Matichencov i Bocharnikova 2001).

Generalnie ubogie w krzem są gleby:

- obojętne i zasadowe o wysokim zasoleniu,

- kwaśne i bardzo kwaśne, silnie zwietrzałe, o wysokim stopniu wymywania (desilizacji) w wilgotnym środowisku,

- piaszczyste, przepuszczalne, zawierające duże ilości krzemionki, ale znikomą zawartość krzemu dostępnego dla roślin $\left(\mathrm{SiO}_{2}\right.$ rozpuszcza w glebie tylko kwas fluorowodorowy, a jej rozkład jest procesem bardzo powolnym),

- organiczne, złożone prawie w całości z próchnicy i materii organicznej (gleby murszowe, histozole), niemal pozbawione minerałów mają z natury niską zawartość krzemu (Epstein i Bloom 2005).

Niedobory krzemu są powszechne w glebach Australii, gdzie składnik ten unieruchamiany jest przez minerały (kwarc, kaolinit), które muszą podlegać wietrzeniu przez wiele lat, zanim krzem zostanie udostępniony roślinie w postaci kwasu krzemowego (Heckman 2013).

\section{Źródła krzemu dla roślin / Sources of silicon for plants}

Od dziesiątek lat krzem stosowany jest systematycznie doglebowo w krajach klimatu tropikalnego, głównie w uprawie ryżu, trzciny cukrowej i kukurydzy oraz w ogrodnictwie. Komercyjne produkty krzemowe są dostępne na całym świecie w postaci stałej lub płynnej. Produkty stałe to naturalne minerały, bądź odpady przemysłowe zawierające krzem: krzemiany wapnia, krzemian magnezu, krzemian potasu, krzemian sodu i dwutlenek krzemu - diatomit tzw. ziemia okrzemkowa. Powszechnie w produkcji polowej na świecie stosowane są krzemiany wapnia. Wollastonit $\left(\mathrm{CaSiO}_{3}\right)$ jest naturalnie występującym, wydobywanym głównie w Chinach i w USA krzemianem wapnia, dopuszczonym do stosowania w rolnictwie ekologicznym (Hodson i wsp. 2005). Drobno zmielony jest doskonałym źródłem krzemu dostępnego dla roślin, neutralizującym kwasowość gleby. Krzemian wapnia jest około 7 razy bardziej rozpuszczalny niż węglan wapnia $\left(\mathrm{CaCO}_{3}\right)$, dzięki czemu jest bardziej skuteczny i działa szybciej. Bogatym źródłem krzemianu wapnia są szeroko wykorzystywane w uprawie trzciny cukrowej i ryżu żużle hutnicze - produkty uboczne m.in. przetwórstwa żelaza. Żużle (zawartość Si około 10\%) różnią się czystością, dostępnością krzemu i zdolnością odkwaszania. Ziemia okrzemkowa (Diatomaceous earth DE) lub diatomit jest skałą osadową, która składa się głównie z pancerzyków okrzemek. Ziemia okrzemkowa występuje w wielu rejonach świata, ma unikalne właściwości fizyczne i zawiera około $80-90 \% \mathrm{SiO}_{2}$ (Sandhya i wsp. 2018). W Polsce niewielkie złoża diatomitów występują w Karpatach, ale ze względu na słabą jakość surowca (zawartość krzemionki rzadko przekracza 75\%) nazywane są skałą lub kopaliną diatomitową.

Stosowanie resztek pożniwnych, obornika i kompostu również zapewnia „Zwrot” krzemu do gleby. Słoma z pszenicy i innych upraw drobnoziarnistych (ryż) może zawierać znaczne ilości krzemu w postaci tzw. „kamieni roślinnych” - fitolitów (Provance-Bowley i wsp. 2010). Miną jednak lata zanim krzem z resztek pożniwnych stanie się dostępny dla roślin, gdyż struktury krzemowe są bardzo odporne na rozkład.

Stosowanie aplikacji dolistnej związkami krzemu jest stosunkowo nowe i datuje się od 1990 roku (Laane 2018). Opryskiwanie krzemem, w zależności od użytego źródła można sklasyfikować jako:

- opryskiwanie krzemianami (krzemiany sodu i potasu),

- opryskiwanie stabilizowanym kwasem krzemowym,

- opryskiwanie innymi związkami Si, np. nanocząsteczkami krzemionki (nano- $\mathrm{SiO}_{2}$ ).

Najwcześniej do aplikacji dolistnej używano dobrze rozpuszczalnych w wodzie krzemianów. W 2003 roku wprowadzono opryskiwanie stabilizowanym kwasem krzemowym (np. aminokwasami), aby zapobiec polimeryzacji cząsteczek kwasu przy ich wysokim stężeniu. W ostatnich latach rozpoczęto także stosowanie opryskiwania dolistnego nanocząsteczkami krzemionki. Nanocząsteczki krzemionki produkowane są m.in. z krzemianu sodu $\left(\mathrm{Na}_{2} \mathrm{SiO}_{3}\right)$. Innym, organicznym źródłem nanocząsteczek krzemionki jest łuska ryżowa. Najczęściej nalistnie stosuje się nano-Si wielkości $20-40 \mathrm{~nm}$.

\section{Wpływ krzemu na plony roślin / Influence of silicon on crop yields}

Zdecydowana większość światowych badań potwierdza dobrą skuteczność stosowania doglebowego krzemu w aspekcie plonowania roślin, przy niskiej zasobności gleb w krzem przyswajalny i warunkach stresowych. Kluczową rolę odgrywa rozpuszczalność i dostępność krzemu z za- 
stosowanego produktu. Pobieranie krzemu przez liście jest natomiast dyskutowane i często podawane w wątpliwość. Niektórzy autorzy uważają, że pierwiastek ten jest w większości, lub nawet całkowicie pobierany przez korzenie (Ma i wsp. 2004; Guevel i wsp. 2007), inni natomiast donoszą o dużej skuteczności dolistnej aplikacji (Othman i wsp. 2020). Uważa się, że opryskiwanie dolistne krzemianami sodu i potasu mogą być skuteczne w działaniu ,jako pestycydy" zapobiegając infekcjom grzybowym, podczas gdy zabiegi opryskiwania stabilizowanym kwasem krzemowym zwiększają wzrost i plonowanie roślin oraz zmniejszają stres biotyczny i abiotyczny (Laane 2018). Danych dotyczących dolistnej aplikacji nano-krzemionki jest niewiele, ale nieliczne opracowania wskazują na tendencję do ograniczenia stresu biotycznego i zmniejszenia stopnia infekcji grzybowych oraz stymulowania wzrostu i plonowania roślin (Suriyaprabha i wsp. 2014). Na podstawie zebranej literatury Laane (2018) przedstawia efekty działania na rośliny trzech form krzemu stosowanego w postaci opryskiwania (tab. 2).

\section{Wyniki światowych badań / Results of global research}

O dobrym działaniu plonotwórczym krzemu świadczą liczne światowe badania. W Kolumbii, w doświadczeniach przeprowadzonych w strefie równikowej, w dwóch lokalizacjach, odnotowano korzystny wpływ nawożenia krzemem na plony i odporność na choroby dwóch odmian ryżu (Seebold i wsp. 2007). Gleby doświadczalne charakteryzował odczyn kwaśny pH 4,4, wysokie wysycenie glinem (18,3\% Al) i minimalna zawartość przyswajalnego $\mathrm{Si}<1$ ppm. Źródłem krzemu dla roślin był krzemian wapnia $\mathrm{CaSiO}_{3}(20 \%$ $\mathrm{Si}$ ), który aplikowano przed sadzeniem ryżu w dawkach 0 , 500 i $1000 \mathrm{~kg} \mathrm{Si} / \mathrm{ha}$. Na poletkach nienawożonych zastosowano wapno rolnicze $\left(\mathrm{CaCO}_{3}\right)$ dla wyrównania poziomu $\mathrm{Ca}$ $\mathrm{w}$ glebie do wniesionego $\mathrm{z}$ wollastonitem. W przypadku obu odmian zastosowanie Si w ilości 500 i $1000 \mathrm{~kg} / \mathrm{ha}$ istotnie zwiększyło plon ziarna, w porównaniu z obiektami bez Si, odpowiednio dla pierwszej i drugiej lokalizacji, o 19 i 24\% i o 40 i $72 \%$. Wzrostowi plonów towarzyszyło zwiększenie zawartości krzemu w liściach o 40\% przy niższej dawce nawozowej i o $60 \%$ przy dawce wyższej, w porównaniu do obiektu bez aplikacji Si.

W Indiach przeprowadzono doświadczenia wazonowe z ryżem (Sandhya i wsp. 2018) z zastosowaniem ziemi okrzemkowej (DE), na trzech typach gleb. Uwzględniono trzy poziomy nawożenia DE: 0, 150, 300, $600 \mathrm{~kg} / \mathrm{ha}$. Ziemia okrzemkowa składała się z biogennej krzemionki, kaolinitu i kwarcu $\left(\mathrm{SiO}_{2}\right)$. Podłoże w doświadczeniach stanowiły gleby (ił gliniasty) pochodzące $\mathrm{z}$ trzech lokalizacji, wykazujące odczyn kwaśny ( $\mathrm{pH} 4,5)$, obojętny $(\mathrm{pH} 6,6)$ i zasadowy (pH 8,81). Sadzonki ryżu po 21 dniach umieszczono w doniczkach i utrzymywano wilgotność gleby $100 \%$ polowej pojemności wodnej (PPW). Największą reakcję na nawożenie $\mathrm{i}$ istotnie najwyższy wzrost biomasy roślin w stosunku do obiektu bez DE odnotowano w glebie alkalicznej/zasadowej (od 0,5 do 6,8 g/waz.), następnie na glebie kwaśnej (od 6,2 do 14,6 g/waz.) i obojętnej (9,4-20,1 g/waz.). Najwyższy plon ziarna uzyskano po aplikacji najwyższej dawki Si (600 kg DE/ha) we wszystkich trzech glebach. Zwyżka plonu na glebie zasadowej wynosiła 45\%, na glebie kwaśnej 29\% i 19\% na glebie obojętnej. Silna reakcja na krzem ryżu rosnącego na glebie kwaśnej, potwierdzona badaniami Tavakkoli i wsp. (2011) dowodzi efektywności działania krzemu. Przy bardzo niskim pH, aplikacja Si ograniczała toksyczność glinu, co wpłynęło na lepszy wzrost roślin. Wyraźną reakcję roślin na krzem w warunkach alkalicznych można tłumaczyć działaniem mechanizmu wypierania przez krzem zaadsorbowanego fosforu, wcześniej niedostępnego dla roślin. Ponadto w warunkach zasadowych, przy istniejącym stresie solnym, korzenie silnie reagowały na nadmiar soli, który ograniczał ich wzrost. Wprowadzenie krzemu w postaci DE skutecznie łagodziło skutki stresu.

W Brazylii, w rejonie tropikalnym (opady około $2000 \mathrm{~mm} / \mathrm{rok}$ ) na znacznym obszarze dominują gleby silnie zwietrzałe, o niskim $\mathrm{pH}$, skrajnie ubogie w fosfor, wapń i krzem dostępny dla roślin. $\mathrm{W}$ doświadczeniu wazonowym

Tabela 2. Schematyczny przegląd efektów działania różnych form opryskiwania dolistnego Table 2. Schematic overview of the effects of the different foliar sprays

\begin{tabular}{l|c|c}
\hline \multicolumn{1}{c|}{$\begin{array}{c}\text { Wpływ } \\
\text { Effects }\end{array}$} & $\begin{array}{c}\text { Krzemiany } \\
\text { Silicates }\end{array}$ & $\begin{array}{c}\text { Stabilizowany kwas krzemowy } \\
\text { Stabilized silicic acid }\end{array}$ \\
\hline 1. Infekcje (stres biotyczny) - Infections (Abiotic stress) & $+/++$ & $+/+$ \\
\hline 2. Stres abiotyczny - Abiotic stress & - & ++ \\
\hline 3. Wzrost korzenia - Root growth & - & $+/++$ \\
\hline 4. Wzrost rośliny (pędy) - Plant growth (shoots) & - & $+/++$ \\
\hline 5. Wielkość liścia - Leaf size & - & ++ \\
\hline 6. Plon - Yield & + & +++ \\
\hline
\end{tabular}

- brak efektu - no effect, + efekt pozytywny - positive effect, ++ efekt dobry - good effect, ND - brak wystarczających danych - no sufficient data available 
(Chagas i wsp. 2016) użyto dwóch gleb (glina piaszczysta) o pH 3,9 i 4,1 w $\mathrm{CaCl}_{2}$ (w $\mathrm{KCl}$ odpowiednio wskaźniki niższe pH 3,6 i 3,9). Gleby w wazonach przed siewem ryżu i prosa perlistego nawieziono wzrastającymi dawkami krzemu: 0, 200, 400 i $800 \mathrm{~kg} \mathrm{Si} /$ ha i porównywano efektywność nawozową trzech źródeł tego pierwiastka dla roślin: 1) krzemianu wapniowo-magnezowego (24,2\% Si, 29,5\% Ca i 1,1\% Mg), 2) wollastonitu (12\% Si, 28\% Ca i 7\% Mg) i 3) czystego kwasu krzemowego (29\% Si). Do wazonów dodano odpowiednie ilości $\mathrm{Ca}$ i $\mathrm{Mg}$ w celu zrównoważenia poziomów tych składników w glebie w obrębie obiektów. Po 30 dniach inkubacji gleby z krzemianem wapnia i krzemianem Ca-Mg stwierdzono, że wraz ze wzrostem dawki liniowo zwiększyła się zawartość przyswajalnego Si w obu glebach doświadczalnych. Stężenie wzrosło z $10 \mathrm{mg} / \mathrm{kg} \mathrm{Si}$ w glebie nienawożonej do $50-60 \mathrm{mg} / \mathrm{kg}$ po zastosowaniu krzemianu Ca-Mg i do $200 \mathrm{mg} / \mathrm{kg}$ Si w przypadku aplikacji wollastonitu. Kwas krzemowy okazał się w glebie absolutnie niereaktywny z uwagi na słabą rozpuszczalność i wniesienie go do gleby nie zwiększyło puli krzemu przyswajalnego dla roślin. Aplikacja do gleby krzemu w postaci minerałów istotnie, równorzędnie zwiększyła plon korzeni i plon ziarna obu testowanych roślin. Dawka $400 \mathrm{~kg} \mathrm{Si} / \mathrm{ha}$ okazała się być dawką optymalną. Pati i wsp. (2016) przedstawiają wyniki podobnego doświadczenia polowego, w którym potwierdzają istotny wpływ ziemi okrzemkowej na plony ryżu uprawianego w strefie aluwialnej w Indiach. W badaniach tych samych autorów wykazano, że krzem istotnie zwiększył parametry wpływające na plon, takie jak wysokość roślin, liczba pędów, liczba wiech, masa 1000 ziaren i w konsekwencji plon ziarna i słomy. Największe zwyżki plonu ziarna i słomy zaobserwowano na obiekcie, gdzie zastosowano DE w dawce $600 \mathrm{~kg} / \mathrm{ha}$ w porównaniu z dawkami niższymi. Ponadto wraz ze wzrostem dawki zwiększyło się stężenie Si, N, P i K w ziarnie i słomie ryżu, co świadczy o dostępności krzemu z tego źródła i jego wpływie na pobieranie składników pokarmowych.

Ahmad i wsp. (2013) badali natomiast skuteczność dolistnego stosowania krzemu w ryżu w doświadczeniu polowym na terenie Pakistanu. Doświadczenie prowadzono na glebie gliniastej, zasadowej $\mathrm{pH} 8,05$, o potencjalnie niskiej zawartości krzemu dostępnego dla roślin. Opryskiwanie roślin wykonano różnymi stężeniami krzemu zawartego w roztworze wodnym: $0 ; 0,25 ; 0,50 ;$ i $1 \%$ Si. Autorzy stwierdzili istotną reakcję roślin na jednorazową aplikację dolistną krzemu w najniższym stężeniu, w postaci wzrostu plonu ziarna ryżu o $17 \%$ i słomy o $14 \%$.

Bocharnikova i wsp. (2010) oceniali wpływ nawożenia krzemem na plonowanie ryżu w doświadczeniu wielkopoletkowym na Florydzie, w którym źródłem krzemu był roztwór kwasu monokrzemowego o stężeniu $150 \mathrm{mg} \mathrm{Si/l}$. Roztwór zastosowano w czasie siewu w dawce 700 1/ha i w trzech terminach dolistnie w dawce 500 1/ha. Na glebie organicznej (histosol), o niskiej zawartości przyswajalnego krzemu aplikacja krzemu w tej formie podwoiła plon ryżu z 1,34 t na obiekcie nienawożonym do 2,6 t/ha.

W innym doświadczeniu, w Kanadzie ci sami autorzy uzyskali w uprawie pszenicy na czarnoziemie (pH 6,5) wzrost plonu ziarna o 55\% po aplikacji mieszanki roztworu kwasu monokrzemowego (200 mg/l) i substancji humusowej $(2 \% \mathrm{C}) \mathrm{w}$ dawce $500 \mathrm{l} / \mathrm{ha}$ w czasie siewu. Naturalne nawożenie krzemem w postaci diatomitu autorzy zastosowali także w uprawie kukurydzy na mikropoletkach w Rosji (Bocharnikova i wsp. 2010). Efektem nawożenia dawką $100 \mathrm{~kg} \mathrm{Si} /$ ha był $20 \%$ wzrost plonów ziarna w stosunku do kontroli.

W Egipcie, Mustafa i wsp. (2016) założyli dwuletnie doświadczenie z kukurydzą na glebie o dużym zasoleniu (ponad $2000 \mathrm{mg} \mathrm{Na} / \mathrm{kg}$ ). Dla złagodzenia stresu solnego u roślin zastosowano zabiegi nalistne w kukurydzy krzemianem potasu w stężeniach: 0, 140, 280, 420 i 560 mg Si/1, 30 dni po siewie i powtórzono 4-krotnie w odstępach $10 \mathrm{dni}$ po pierwszej dawce. Zwiększenie dawki dolistnej krzemu wpłynęło na istotny wzrost plonu biomasy, masy 1000 ziaren i w efekcie plonu ziarna, maksymalnie o $24 \%$ przy dawce $420 \mathrm{mg} \mathrm{Si} / \mathrm{l}$. Zwiększyła się również zawartość białka w ziarnie z 91 do $98 \mathrm{~g} / \mathrm{kg}$. Zaobserwowano także postępujący wzrost koncentracji N, P i K w liściach wraz z wielkością dawki. Spadła natomiast ponad trzykrotnie koncentracja $\mathrm{Na}$ w roślinach, co wskazuje, że aplikacja krzemu złagodziła wpływ stresu solnego u roślin rosnących na glebach gliniastych sodowych (pH gleby doświadczalnej 8,3 w $\mathrm{H}_{2} \mathrm{O}$ ). Odmienne wyniki prezentują natomiast badania Freitasa i wsp. (2011), w których autorzy po trzykrotnym zabiegu nalistnym w kukurydzy nie uzyskali pożądanego efektu w postaci zwyżki plonu. Zasilenie roślin krzemem poprzez aplikację dolistną w dawkach 130, 260, 390 i 520 g Si/ha nie zmieniało wielkości plonu ziarna, parametrów plonu i koncentracji chlorofilu w liściach w stosunku do obiektu bez Si. Krzem wniesiony „na liść” spowodował jedynie niewielką zmianę zawartości krzemu w liściach.

Aplikacja dolistna krzemem nie zawsze przynosi dobre rezultaty. Naukowcy brazylijscy (Segalin i wsp. 2012) w ścisłym polowym eksperymencie testowali reakcję pięciu odmian pszenicy na dwie dawki (3 i 6 1/ha) preparatu krzemowego. W badaniach użyto gleby typowej dla klimatu wilgotnego tropikalnego (argisol). W doświadczeniu zastosowano zapobiegawcze środki kontroli chemicznej. Uprawa była wolna od szkodników i chorób, czyli stresu, na który skutecznie wpływa krzem. Uzyskane wyniki wykazały, że dolistna aplikacja krzemu nie wpłynęła na plon ani jakość fizjologiczną nasion uprawianych odmian pszenicy. Reakcji plonotwórczej na nawożenie krzemem ryżu nawadnianego nie stwierdzili również Marchesan i wsp. (2004). Doglebowe dawki 1000, 2000, $4000 \mathrm{~kg} / \mathrm{ha}$ $\mathrm{CaSiO}_{3} \mathrm{w}$ trzyletnim doświadczeniu okazały się nieskuteczne. Jak podają autorzy, rośliny rosnące w dogodnych warunkach nie zawsze reagują na krzem. Korzystne dzia- 
łanie krzemu uwidacznia się szczególnie w warunkach stresowych.

Badania nad wpływem krzemu na plony roślin były prowadzone również w Polsce. Artyszak i wsp. (2015) założyli w południowo-wschodniej Polsce na wapiennych czarnoziemach (pH gleb 6,7; 7,3) dwuletnie doświadczenie polowe $\mathrm{z}$ dokarmianiem dolistnym krzemem buraka cukrowego. W eksperymencie zastosowano dwa rodzaje płynnych nawozów: 1) produkt zawierający 7,99\% Si i 26,2\% Ca aplikowany w dawce $1,5 \mathrm{~kg} / \mathrm{ha}$; 2) produkt zawierający $94,1 \mathrm{~g} \mathrm{Si}$ i $24 \mathrm{~g} \mathrm{Fe} \mathrm{w} 1 \mathrm{dm}^{3} \mathrm{w}$ dawce $0,5 \mathrm{dm}^{3} /$ ha (stabilizowany kwas krzemowy). W porównaniu z kontrolą dolistne nawożenie wapniem i krzemem przyniosło średnio $12,6 \%$ wzrost plonu korzeni (z 10,4 do 16,2\%) w stosunku do zastosowanej dawki. Dolistna aplikacja krzemu bez wapnia spowodowała średnio 14,5\% wzrost plonu korzeni z 13,7 do $15,9 \%$. Zastosowanie obu produktów krzemowych skutkowało istotnym, kilkunastoprocentowym wzrostem biologicznego i technologicznego plonu cukru w buraku. Pod wpływem aplikacji krzemu odnotowano w doświadczeniu wzrost parametrów fizjologicznych buraka (Artyszak i wsp. 2016). Plony korzeni buraka cukrowego i cukru technologicznego były silnie dodatnio skorelowane z absorpcją PAR (promieniowanie fotosyntetycznie aktywne) i LAI (wskaźnik powierzchni liścia).

Najnowsze badania prowadzone w warunkach glebowych naszego kraju przez Kowalską i wsp. (2020) wskazują na korzystny wpływ nawozów krzemowych na wzrost i rozwój pszenicy jarej w uprawie ekologicznej. W dwuletnim, ścisłym doświadczeniu polowym prowadzonym na dwóch glebach o pH 6,0 i 6,2 zaaplikowano pod pszenicę jarą produkty krzemowe w różnej formie. Zastosowano sproszkowany diatomit (89-95\% $\mathrm{SiO}_{2}$ ) w dawce $10 \mathrm{~kg} / \mathrm{ha}$ oraz produkt ciekły, $24 \%$ roztwór kwasu monokrzemowego $\mathrm{w}$ dawce $0,3 \mathrm{l} / \mathrm{ha}$. Oba produkty testowano w trzech kombinacjach: 1) doglebowo, przed siewem, 2) dolistnie, dwukrotne opryskiwanie (faza krzewienia i początek kwitnienia), 3) doglebowo i dolistnie. Zaaplikowany krzem spowodował istotne zwiększenie plonów pszenicy. Najlepszy efekt plonotwórczy uzyskano stosując opryskiwanie dolistne płynnym produktem zawierającym kwas krzemowy dostępny dla roślin (25\% zwyżka plonu w stosunku do obiektu bez Si) i w kombinacji aplikacja doglebowa + dolistna (28\% wzrost plonu). Podobny efekt autorzy uzyskali po podwójnej aplikacji ziemi okrzemkowej przedsiewnie i dolistnie w roztworze wodnym ( $38 \%$ zwyżka plonu).

$\mathrm{Z}$ przedstawionego przeglądu badań wynika, że przy niedoborze w glebie krzemu przyswajalnego i w warunkach stresowych dla roślin, stosowanie krzemu może wpływać pozytywnie na kondycję, wielkość i jakość plonów. Uzyskane efekty plonotwórcze zależą głównie od rozpuszczalności i przyswajalności krzemu z zastosowanego produktu, wielkości dawki, stężenia kwasu krzemowego aplikowanego dolistnie i fazy rośliny uprawnej. Zagadnienie efektywności działania krzemu w uprawie roślin, szczególnie w naszej strefie klimatycznej wymaga kontynuowania badań.

\section{Literatura / References}

Ahmad A., Afzal M., Ahmad A.U.H., Tahir M. 2013. Effect of foliar application of silicon on yield and quality of rice (Oryza sativa L). Cercetari Agronomice in Moldova 46 (3): 21-28. DOI: 10.2478/v10298-012-0089-3

Artyszak A., Gozdowski D., Kucińska K. 2015.The effect of silicon foliar fertilization in sugar beet - Beta vulgaris (L.) ssp. vulgaris conv. crassa (Alef.) prov. altissima (Döll). Turkish Journal of Field Crops 20 (1): 115-119. DOI: 10.17557/.90799

Artyszak A., Gozdowski D., Kucińska K. 2016. Effect of foliar fertilization with silicon on the chosen physiological features and yield of sugar beet. [Wpływ dokarmiania dolistnego krzemem na wybrane cechy fizjologiczne i plonowanie buraka cukrowego]. Fragmenta Agronomica 33 (2): 7-14.

Bocharnikova E.A., Loginov S.V., Matychenkov V.V., Storozhenko P.A. 2010. Silicon fertilizer efficiency. Russian Agricultural Science 36: 446-448. DOI: 10.3103/S1068367410060157

Brogowski Z. 2000. Krzem w glebie i jego rola w żywieniu roślin. Postępy Nauk Rolniczych 47 (6): 9-16.

Chagas R.C.S., Muraoka T., Korndörfer G.H., Camargo M.S. 2016. Silicon fertilization improve yield and quality of rice and pearl millet in cerrado soils. Bioscience Journal 32 (4): 899-907. DOI: 10.14393/BJ-v32n4a2016-32792

Epstein E., Bloom A.J. 2005. Mineral Nutrition of Plants: Principles and Perspectives. Second edition. Sinauer Associates is an imprint of Oxford University Press, 380 ss. ISBN 978-0878931729.

Farooq M.A., Dietz K.J. 2015. Silicon as versatile player in plant and human biology: overlooked and poorly understood. Frontiers in Plant Science 6: 994. DOI: 10.3389/fpls.2015.00994

Freitas L.B., Coelho E.M., Maia S.C.M., Silva T.R.B. 2011. Foliar fertilization with silicon in maize. Revista Ceres 58 (2): $262-267$.

Gao X., Zou C., Wang L., Zhang F. 2004. Silicon improves water use efficiency in maize plants. Journal of Plant Nutrition 27 (8): 1457-1470. DOI: 10.1081/PLN-200025865

Gao X., Zou C., Wang L., Zhang F. 2006. Silicon decreases transpiration rate and conductance from stomata of maize plants. Journal of Plant Nutrition 29 (9): 1637-1647. DOI: 10.1080/01904160600851494

Guével M.-H., Menzies J.G., Bélanger R.R. 2007. Effect of root and foliar applications of soluble silicon on powdery mildew control and growth of wheat plants. European Journal of Plant Pathology 119 (4): 429-436. DOI: 10.1007/s10658-007-9181-1

Heckman J. 2013. Silicon: a beneficial substance. Better Crops with Plant Food 97 (4): 14-16.

Hodson M.J., White P.J., Mead A., Broadley M.R. 2005. Phylogenetic variation in the silicon composition of plants. Annals of Botany 96 (6): 1027-1046. DOI: $10.1093 / \mathrm{aob} / \mathrm{mci} 255$

Knight C.T.G., Kinrade S.D. 2001. A primer on the aqueous chemistry of silicon. s. 57-84. W: Silicon in Agriculture (L.E. Datnoff, G.H. Snyder, G.H. Korndörfer, red.). Elsevier Science, Amsterdam, 42 ss. ISBN 9780444502629. 
Kowalska J., Tyburski J., Jakubowska M., Krzymińska J. 2020. Effect of different forms of silicon on growth of spring wheat cultivated in organic farming system. Silicon: 1-7. DOI: 10.1007/s12633-020-00414-4

Laane H.M. 2011. Foliar silicic acid technology for plants. Proceedings of the 5th International Conference on Silicon in Agriculture. Beijing, China, September 13-18, 2011: 99-100.

Laane H.M. 2018. The effects of foliar sprays with different silicon compounds. Plants 7 (2): 45. DOI: 10.3390/plants7020045

Liang Y., Wong J.W.C., Wei L. 2005. Silicon-mediated enhancement of cadmium tolerance in maize (Zea mays L.) grown in cadmium contaminated soil. Chemosphere 58 (4): 475-483. DOI: 10.1016/j.chemosphere.2004.09.034

Lumsdon D.G., Farmer V.C. 1995. Solubility characteristics of proto-imogolite sols: how silicic acid can de-toxify aluminium solutions. Soil Science 46 (2): 179-186. DOI: 10.1111/j.1365-2389.1995.tb01825.x

Ma J.F. 2004. Role of silicon in enhancing the resistance of plants to biotic and abiotic stresses. Soil Science Plant Nutrition 50 (1): 11-18. DOI: $10.1080 / 00380768.2004 .10408447$

Ma J.F., Mitani N., Nagao S., Konishi S., Tamai K., Iwashita T., Yano M. 2004. Characterization of the silicon uptake system and molecular mapping of the silicon transporter gene in rice. Plant Physiology 136 (2): 3284-3289. DOI: 10.1104/pp.104.047365

Marchesan E., Villa S.C.C., Marzari V., Korndorfer G.H., Santos M. 2004. Silicon application on flooded rice in production components. Bioscience Journal 20 (3): 125-131.

Matichencov V.V., Bocharnikova E.A. 2001. The relationship between silicon and soil physical and chemical properties. s. 209-219. W: Silicon in Agriculture (L.E. Datnoff, G.H. Snyder, G.H. Korndörfer, red.). Elsevier Science, Amsterdam, 42 ss. ISBN 9780444502629.

Matichenkov V.V., Calvert D.V. 2002. Silicon as a beneficial element for sugarcane. Journal American Society of Sugarcane Technologists 22: $21-30$.

Mustafa M.A., Metwallyl S.M., Ibrahim M.A. 2016. Assessing the effect of silicon fertilization on the productivity of maize (Zea mays L.) grown in a clay sodic soil. Zagazig Journal of Agriculture Research 43 (5): 1561-1569. DOI: 10.21608/zjar.2016.98106

Othman A., Ayed S., Bezzin O., Farooq M., Ayed-Slama O., Slim-Amara H., Younes M.B. 2020. Effect of silicon supply methods on durum wheat (Triticum durum Desf.) response to drought stress. Silicon: 1-11. DOI: 10.1007/s12633-020-00639-3

Pati S., Pal B., Badole S., Hazra G.C., Mandal B. 2016. Effect of silicon fertilization on growth, yield, and nutrient uptake of rice. Communications in Soil Science and Plant Analysis 47 (3): 284-290. DOI: 10.1080/00103624.2015.1122797

Provance-Bowley M.C., Heckman J.R., Durner E.F. 2010. Calcium silicate suppresses powdery mildew and increases yield of field grown wheat. Soil Science Society of America Journal 74 (5): 1652-1661. DOI: 10.2136/sssaj2010.0134

Sahebi M., Hanafi M.M., Akmar A.S.N., Rafii M.Y., Azizi P., Tengoua F.F., Azwa J.N.M., Shabanimofrad M. 2015. Importance of silicon and mechanisms of biosilica formation in plants. BioMed Research International, Volume 2015, Article ID 396010,16 ss. DOI: $10.1155 / 2015 / 396010$

Sandhya K., Prakash N.B., Meunier J.D. 2018. Diatomaceous earth as source of silicon on the growth and yield of rice in contrasted soils of Southern India. Journal of Soil Science and Plant Nutrition 18 (2): 344-360. DOI: 10.4067/S0718-95162018005001201

Seebold K.W., Datnoff L.E., Correa-Victoria F.J., Kucharek T.A., Snyder G.H. 2000. Effect of silicon rate and host resistance on blast, scald, and yield of upland rice. Plant Disease 84 (8): 871-876. DOI: 10.1094/PDIS.2000.84.8.871

Segalin S.R., Huth C., D'Avila Rosa T., Pahins D.B. 2012. Foliar application of silicon and the effect on wheat seed yield and quality. Journal of Seed Science 35 (1): 86-91. DOI: 10.1590/S2317-15372013000100012

Sommer M., Kaczorek D., Kuzyakov Y., Breuer J. 2006. Silicon pools and fluxes in soils and landscapes - a review. Journal of Plant Nutrition and Soil Science 169 (3): 310-329. DOI: 10.1002/jpln.200521981

Suriyaprabha R., Karunakaran G., Yuvakkumar R., Rajendran V., Kannan N. 2014. Foliar application of silica nanoparticles on the phytochemical responses of maize (Zea mays L.) and its toxicological behavior. Journal Synthesis and Reactivity in Inorganic and Nano-Metal Chemistry 44 (8): 1128-1131. DOI: 10.1080/15533174.2013.799197

Tavakkoli E., Lyons G., English P., Guppy C.N. 2011. Silicon nutrition of rice is affected by soil pH, weathering and silicon fertilization. Journal of Plant Nutrition and Soil Science 174 (3): 437-446. DOI: 10.1002/jpln.201000023

Tubana B.S., Babu T., Datnoff L.E. 2016. A review of silicon in soils and plants and its role in US agriculture: history and future perspectives. Soil Science 181 (9/10): 393-411. DOI: 10.1097/SS.0000000000000179 